Vol. 14 (2005): 346-353.

\title{
Introduction of automatic milking system in Finland: effect on milk quality
}

\author{
Heidi Salovuo, Pilvi Ronkainen, Antti Heino \\ Department of Food Technology, PO Box 66, FI-00014 University of Helsinki, Finland \\ Antti Suokannas \\ MTT Agrifood Research Finland, Agricultural Engineering Research, Vakolantie 55, FI-03400 Vihti, Finland \\ Eeva-Liisa Ryhänen \\ MTT Agrifood Research Finland, Food Research, FI-31600 Jokioinen, Finland, e-mail: eeva-liisa.ryhanen@mtt.fi
}

\begin{abstract}
When an automatic milking system (AMS) is introduced on a farm the milking of cows and related work is changed in many ways compared to farms with traditional milking systems. The objective of this paper was to study the effect of the introduction of robotic milking in Finland on the composition and hygienic quality of milk. The study was carried out on three farms which were the first in Finland to introduce the automatic milking system (Volontary Milking System ${ }^{\mathrm{TM}}$ ). Main chemical composition, somatic cell count, total bacteria count, freezing point, free fatty acids, as well as Bacillus cereus, Clostridium spores, psychrotrophic bacteria and coliforms were determined. After the introduction of the automatic milking system an increase in somatic cell count and total bacteria count, psychrotrophic bacteria and coliforms was observed; however, the differences were not statistically significant. The counts for Clostridium spores were at the same level in the automatic and the conventional milking system. Bacillus cereus counts were very low in both milking systems studied. Milk fat content and free fatty acids were elevated when AMS was introduced. The introduction of AMS resulted in a significant increase $(\mathrm{P}<0.01)$ in the freezing point during the first three months. Though there was a trend that the overall quality of milk was impaired after the introduction of AMS, the quality of milk remained at premium class.
\end{abstract}

Key words: automatic milking, milk quality, somatic cell count, total bacteria count

\section{Introduction}

The first automatic milking system (AMS) was introduced in the Netherlands in the beginning of the 1990s. Since then the AMS has been installed at a number of farms in Europe, USA and Japan. In
Finland the system was introduced in 2000 and the number of farms with AMS has steadily increased since then.

The milking of cows changes in many ways when traditional milking systems are replaced by an AMS. The system includes voluntary visits for milking and milking may occur more than twice 
Vol. 14 (2005): 346-353.

daily. In AMS human presence is not required during milking. The machine prepares the cow for milking independently according to settings that are pre-programmed. The AMS includes the cleaning of teats in order to minimise the transmission of mastitis or other harmful bacteria. The machine is also programmed to indicate cows with abnormal milk or milk with high somatic cell count (SCC), by use of different sensors. The cleaning process of milking equipment is automatic and is carried out two to three times a day ( $24 \mathrm{~h})$. After an idle period the milking equipment is automatically flushed. A flush is also given when a cow with abnormal milk, for example with a high SCC, has visited the milking unit. (Schuling et al. 2001)

The effects of AMS on udder health and milk quality have been evaluated in a number of experiments. According to several studies the total bacteria counts (TBC) and SCC and the free fatty acid (FFA) level elevate after the introduction of AMS (van der Vorst and Hogeveen 2000, Everitt et al. 2002, Rasmussen et al. 2002). However, no effects (Klungel et al. 2000) or even an improvement (Berglund et al. 2002) in SCC have also been reported. The health, stage of lactation, (living) environment and feeding of the animal affects the quality and chemical composition of milk (Akam et al. 1989). Elevated SCC are usually a sign of mastitis. The TBC of milk is an indicator of the milking hygiene and the cooling of milk but can also imply hazards in animal health (Hayes et al. 2000). It has been suggested that factors related to AMS, such as increased milking frequency, may also have an impact on milk quality (Escobar and Bradley 1990, Hamann and Gyodi 2000, Klungel et al. 2000, Hogeveen et al. 2001). Klungel et al. (2000) suggested that increased levels of free fatty acids may be partly explained by shorter intervals. According to Hogeveen et al. (2001) the variation in the milking interval could be part of the explanation for an apparent increase in SCC with automatic milking. However, more research on the relationships between milking intervals and milk quality is required.

The present study was carried out as part of a larger Finnish project investigating the impact of AMS on udder health, animal welfare and milk quality on three Finnish farms. The objective of this work was to study the effect of the introduction of robotic milking on the composition and hygienic quality of milk.

\section{Material and methods}

\section{Dairy cows and milking}

Three farms participated in this study; two private farms (PF1 and PF2) and the Helsinki University's research farm. The farms are located in southwestern Finland. The research farm had an average 26 cows and private farms from 33 to 55 cows. The cows were mainly of the Holstein Friesian breed.

The cows were milked with the Voluntary Milking System ${ }^{\mathrm{TM}}$ (VMS; DeLaval Group, Tumba, Sweden). The mean milking frequency was 2-3 times per day. The AMS included the cleaning of the teats with a special teat cup. After milking the teat cups were automatically detached.

\section{Collection and analysis of milk samples}

Bulk tank milk samples were collected once a week for three months on the research farm and farm PF2 before the new milking equipment was adopted. From farm PF1 samples were taken once a week for one month before installation. After installation of the new equipment bulk tank milk samples were collected twice a week during the first three months and later on once a week from all farms. The samples were taken for the first year of using AMS during years 2000 and 2001. Before drawing samples from farm tank, milk was stirred for five minutes. Samples were stored in refrigerator at $+4^{\circ} \mathrm{C}$ and transported to the laboratory by milk-lorry within 24 hours.

The results were compared to a reference group which included the conventional milking parlour of the research farm and 26 farms on a milk collecting route located in south-western Finland. 
The fat, protein and lactose content $\left(\mathrm{g}^{-1}\right)$, SCC (cells $\mathrm{ml}^{-1}$ ) and freezing point $\left({ }^{\circ} \mathrm{C}\right)$ were determined using CombiFoss 6000, (Foss A/S, Hillerod, Denmark), which is a combination of MilcoScan FT 600 and Fossomatic 5000. The TBC (cfu ml-1) was determined by automated fluorescence microscopy (BactoScan 8000, Foss A/S, Hillerod, Denmark). The samples were analysed by Valio Ltd Kouvola until 1 April 2001 and after that by Valio Ltd Seinäjoki.

Milk samples to analyse of FFA were collected once a week for seven months (research farm and PF1) or for four months (PF2) after installation of AMS. The FFA (mEq $100 \mathrm{~g}^{-1}$ fat) were determined according to the method of FIL-IDF (1989) with slight modification.

Bacillus cereus count in raw milk was determined using the ISO method 7932 (ISO 7932). In total 19 samples were taken from the three AMS equipments during a period from November 2001 to February 2002. Control samples $(n=20)$ were taken from conventional milking parlours. Clostridium spores were determined according to Bergere and Sivelä (1990) from samples collected once a week for seven months from April to October $2001(n=60)$. Samples from conventional milking parlours $(n=84)$ were taken in April, May and October 2001.

Psychrotrophic bacteria and coliforms were also determined from bulk milk samples. Samples were collected once a week for seven months after the introduction of AMS. The determination of coliforms was performed using a standard method (FIL-IDF 1985). Psychrotrophic bacteria were determined according to the IDF Standard (FIL-IDF 1991). All determinations were performed in duplicate.

\section{Statistical analysis}

The study was divided into five periods: the first period was before AMS was adopted. The following periods are 1-3, 4-6, 7-9 and 10-12 months after installation. Mean values for the parameters were calculated separately for each farm. From these results an overall mean and standard deviation were calculated.
Geometric means and standard deviation (SD) were calculated for the SCC and TBC. Arithmetic means and SD were calculated for fat, protein and lactose content as well as for the freezing point.

The data were statistically analysed by analysis of variance using SPSS 9.0 statistical software. Statistical analyses were only performed to normally distributed parameters within the test group. Within the group differences were tested with Tukey's test.

\section{Results}

\section{Somatic cell count and total bacteria count}

TBC and SCC are presented in Table 1. The SCC elevated from $142000(\log 5.15)$ to $208000(\log$ 5.31) cells ml-1 during the first nine months compared to the situation before installation of AMS. There was a slight improvement in SCC during the last period, which can be seen as a decrease of cell count by $32000(\log 0.07)$ cells $\mathrm{ml}^{-1}$. The TBC was elevated about three fold during the AMS period from $3800(\log 3.54)$ to $12400(\log 4.07) \mathrm{cfu} \mathrm{ml}^{-1}$. However, the increases in SCC and TBC were not statistically significant $(\mathrm{P}>0.05)$.

\section{Coliforms and psychrotrophic bacteria}

The count of coliforms bacteria in AMS was elevated compared to traditional system. The coliformic counts (geometric mean) were $57 \mathrm{cfu} \mathrm{ml}^{-1}$ and $18 \mathrm{cfu} \mathrm{ml}^{-1}$ for AMS-milk and conventional milk, respectively. The variation in bacterial counts was substantial; in the AMS-milk the highest counts were $28000 \mathrm{cfu} \mathrm{ml}^{-1}$ and in the reference group 9 $900 \mathrm{cfu} \mathrm{ml}^{-1}$. As can be seen in Table 2, counts over $100 \mathrm{cfu} \mathrm{ml}^{-1}$ are more frequent in AMS milk than in conventional milk. The count of psychrotrophic bacteria in AMS-milk was $1281 \mathrm{cfu} \mathrm{ml}^{-1}$ and was 10 fold higher than in the reference group (119 cfu $\left.\mathrm{ml}^{-1}\right)$. 
Vol. 14 (2005): 346-353.

Table 1. The somatic cell count and total bacteria count in milk before and after the introduction of the automatic milking system in three months periods.

\begin{tabular}{lcccc}
\hline & \multicolumn{2}{c}{$\begin{array}{c}\text { Somatic cell count } \\
(\text { Log cells ml }\end{array}$} & \multicolumn{2}{c}{$\begin{array}{c}\text { Total bacteria count } \\
\left(\text { Log cfu ml }^{-1}\right)\end{array}$} \\
& $\begin{array}{l}\text { Geometric mean } \\
\text { Standard deviation }\end{array}$ & $\begin{array}{c}\text { Geometric mean Standard deviation } \\
\text { Before introduction }\end{array}$ \\
After introduction, months & 5.15 & 0.16 & 3.54 & 0.54 \\
$1-3$ & 5.22 & & & \\
$4-6$ & 5.29 & 0.11 & 3.92 & 0.21 \\
$7-9$ & 5.31 & 0.10 & 3.96 & 0.37 \\
$10-12$ & 5.24 & 0.12 & 4.05 & 0.18 \\
\hline
\end{tabular}

Table 2. Coliforms in milk produced using automatic milking system $(n=56)$ or by conventional parlour milking $(\mathrm{n}=72)$.

\begin{tabular}{|c|c|c|c|c|}
\hline \multirow[t]{2}{*}{ cfu ml-1 } & \multicolumn{2}{|c|}{$\begin{array}{c}\text { Automatic } \\
\text { milking system }\end{array}$} & \multicolumn{2}{|c|}{ Conventional } \\
\hline & $\mathrm{n}$ & $\%$ & $\mathrm{n}$ & $\%$ \\
\hline$<100$ & 35 & 63.5 & 55 & 76.4 \\
\hline $100-1000$ & 15 & 26.8 & 15 & 20.8 \\
\hline$>1000$ & 6 & 10.7 & 2 & 2.8 \\
\hline
\end{tabular}

$\mathrm{n}=$ number of observations

\section{Bacillus cereus and Clostridium spores}

In the present study the content of Bacillus cereus in raw milk was very low $\left(1 \mathrm{cfu} \mathrm{ml}^{-1}\right)$ and bacteria were detected in only two of the 39 raw milk samples studied (one positive sample in each groups). The level of Clostridium spores is presented in Table 3 showing that the majority of the raw milk samples contained Clostridium spores under 300 $1^{-1} ; 80$ and $83 \%$, in conventional and AMS, respectively. Most of the samples had less than 1 spore $\mathrm{ml}^{-1}$.

\section{Main chemical composition, freezing point and free fatty acids}

The fat content of milk was elevated from 3.85 up to $4.20 \%$ when AMS was introduced. However, the increase was not statistically significant. Only minor changes in protein and lactose content were detected after introduction of AMS (Table 4).
Table 3. Clostridium spores in milk produced using automatic milking system $(n=60)$ or by conventional parlour milking $(\mathrm{n}=84)$.

\begin{tabular}{lrrrr}
\hline \multirow{2}{*}{$\begin{array}{l}\text { Most propable } \\
\text { number } \mathrm{l}^{-1}\end{array}$} & \multicolumn{2}{c}{ Automatic } & \multicolumn{2}{c}{ Conventional } \\
& \multicolumn{2}{c}{ milking system } & & \\
& $\mathrm{n}$ & $\%$ & $\mathrm{n}$ & $\%$ \\
\hline$<300$ & 50 & 83.3 & 69 & 82.1 \\
$300-1000$ & 8 & 13.3 & 10 & 11.9 \\
$>1000$ & 2 & 3.3 & 5 & 6.0 \\
\hline
\end{tabular}

$\mathrm{n}=$ number of observations

The freezing point (FP) elevated significantly $(\mathrm{P}<0.01)$ from -0.531 to $-0.518^{\circ} \mathrm{C}$ during the first three months after the introduction of AMS. After that the FP returned to the same level as before AMS (Table 4).

The introduction of AMS elevated the level of FFA. The mean values $( \pm \mathrm{SD})$ were $0.52 \pm 0.09$ and $0.82 \pm 0.16 \mathrm{mEq} 100 \mathrm{~g}^{-1}$ fat for conventional milking $(n=40)$ and AMS $(n=88)$, respectively.

\section{Discussion}

Even though in the present study the TBC and SCC had a tendency to increase, the quality of milk still remained good. The upper limits for high quality milk in Finland (E-class, extra) are for the SCC 250000 cells ml $^{-1}$ (log 5.40) (3 months geometric mean) and for the TBC $50000 \mathrm{cfu} \mathrm{ml}^{-1}$ (log 4.70) (2 months geometric mean). In present study the levels measured did not exceed these limits. 
Salovuo, H. et al. Introduction of automatic milking

Table 4. The chemical composition and freezing point of milk before and after the introduction of the automatic milking system in three months periods. Values are arithmetic means.

\begin{tabular}{|c|c|c|c|c|c|c|c|c|}
\hline & \multicolumn{2}{|c|}{$\begin{array}{l}\text { Fat } \\
\left(\mathrm{g} \mathrm{l}^{-1}\right)\end{array}$} & \multicolumn{2}{|c|}{$\begin{array}{l}\text { Protein } \\
\left(\mathrm{g} \mathrm{l}^{-1}\right)\end{array}$} & \multicolumn{2}{|c|}{$\begin{array}{c}\text { Lactose } \\
\left(\mathrm{g} \mathrm{l}^{-1}\right)\end{array}$} & \multicolumn{2}{|c|}{ Freezing point $\left({ }^{\circ} \mathrm{C}\right)$} \\
\hline & Mean & SD & Mean & SD & Mean & $\mathrm{SD}$ & Mean & SD \\
\hline Before introduction & 38.5 & 3.3 & 33.5 & 1.6 & 49.1 & 0.6 & $-0.531^{\mathrm{a}}$ & 0.003 \\
\hline $\begin{array}{l}\text { After introduction, months } \\
1-3 \\
4-6 \\
7-9 \\
10-12\end{array}$ & $\begin{array}{l}39.7 \\
42.0 \\
40.3 \\
40.4\end{array}$ & $\begin{array}{l}1.4 \\
2.0 \\
0.8 \\
1.1\end{array}$ & $\begin{array}{l}32.1 \\
33.1 \\
33.6 \\
33.6\end{array}$ & $\begin{array}{l}1.0 \\
0.5 \\
0.9 \\
0.2\end{array}$ & $\begin{array}{l}48.1 \\
48.4 \\
48.5 \\
48.6\end{array}$ & $\begin{array}{l}0.4 \\
0.2 \\
0.5 \\
0.5\end{array}$ & $\begin{array}{l}-0.518^{\mathrm{b}} \\
-0.524^{\mathrm{ab}} \\
-0.528^{\mathrm{ab}} \\
-0.530^{\mathrm{a}}\end{array}$ & $\begin{array}{l}0.002 \\
0.002 \\
0.005 \\
0.002\end{array}$ \\
\hline
\end{tabular}

a,b values within same column marked with different letters are statistically different $(\mathrm{P}<0.01)$

$\mathrm{SD}=$ standard deviation

Since 1998 over 90\% of Finnish milk has been in the E-class (Finnish Association for Milk hygiene 2004). It can be suggested that although some adverse effects on milk quality were observed, the overall hygienic quality of milk was not markedly changed by the introduction of AMS. However the amount of data was quite small, the variation in counts was high and there was only three farms participating in the study. Also the farms differed from each other among other things in feeding, living environment and hygienic status. Moreover, it should be noted that one farm was a research farm.

Others have also reported increases in TBC and SCC due to the introduction of AMS. In the Netherlands, according to Klungel et al. (2000), the TBC increased from 8000 to $19000 \mathrm{cfu} \mathrm{m}^{-1}$, although the SCC did not rise after the introduction of AMS. Van der Vorst and Hogeveen (2000) discovered that both TBC (from 8000 to 12000 cfu ml-1) and SCC (181000 to 192000 cells ml-1) increased during the first year of automatic milking. In Denmark the TBC increased from 7400 to $14000 \mathrm{cfu} \mathrm{ml}^{-1}$ and the SCC increased from 246000 to 302000 cells ml $^{-1}$ (Rasmussen et al. 2002). Increase in TBC may be caused by failures in the cleaning system (Hayes et al. 2000). The main reason for high SCC seems to be that farms with AMS have been reported to have more new infections during the first year of AMS (Rasmussen et al. 2001). The same phenomenon was also found in our larger project studying the impact of
AMS on udder health and animal welfare. According to this larger study significantly more infections were reported on all farms. Unreliable detection of subclinical infections was suggested to be the most important reason for increase of infections (Suokannas et al. 2005).

Coliforms are an indicator of milking and cowhouse hygiene, especially environmental contamination. According to Schuling et al. (2001), the amount of coliforms in raw milk should be below $100 \mathrm{cfu} \mathrm{ml}^{-1}$. High counts of coliforms can be attributed to coliform mastitis or environmental contamination (Hayes et al. 2000). In this study the high counts of coliforms might originate from environmental contamination which could have been caused by temporary problems in the cleaning process.

The count of psychrotrophic bacteria in AMSmilk was 10 fold higher than in the reference group. Sources of contamination of psychrotrophs include soil, dust, air, water, vegetation and faeces as well as milking equipment (Shah 1994). Higher psychrotrophic counts in this study may be an indication of failures in the AMS cleaning system. Psychrotrophic bacteria can cause problems in the manufacture of milk products, such as cheese making, due to enzymatic activity when counts increase to $10^{4}-10^{7} \mathrm{cfu} \mathrm{m}^{-1}$ (Cromie 1992). The counts of psychrotrophic bacteria in this study remained below $10^{4} \mathrm{cfu} \mathrm{ml}^{-1}$ and represented a share under $10 \%$ of total bacteria indicating good milking hygiene. 
Vol. 14 (2005): 346-353.

In our study the content of Bacillus cereus in raw milk was very low. Bacillus cereus is a well known organism of food poisoning and a common contaminant in raw milk (te Giffel et al. 1995). The spore content in milk is strongly associated with the degree of contamination of the teats with soil Christiansson et al. (1999). According to Christiansson et al. (1999) the milking equipment, the air in the barn and animal feeding do not significantly affect the spore content. Slaghuis et al. (1997) reported that restricted pasturing during summer reduced the contamination level of milk and suggested that automatic milking will lower the level of Bacillus spores in milk. To our knowledge, so far no reports on the incidence of Bacillus cereus in milk produced by an AMS have been published. Our study suggests that AMS poses no risk for contamination of aerobic spores.

Clostridium spores represent a minority of bacteria found in raw milk, contamination levels being around $10-10^{2}$ spores $\mathrm{ml}^{-1}$. If lactating cows are fed with heavily contaminated silage, levels can increase to over $10^{3}$ spores $\mathrm{ml}^{-1}$ (Aureli and Franciosa 2002). Spores in milk originate from the udder, and go from the teats and teat cups to the milk. Dirty cows, spores in the air and milking equipment also affect the butyric acid bacteria content of milk (Stadhouders and Jørgensen 1990). In contrast to our study, Rasmussen et al. (2002) reported a significant increase in spores of anaerobes going from conventional to automatic milking, and this phenomenon was observed throughout the first year. Most of the clostridial species relevant in dairy products are nonpathogenic for humans but can cause defects in final products (Aureli and Franciosa 2002) such as late blowing in hard cheese caused by Clostridium tyrobutyricum (Klijn et al. 1995).

The fat content of milk tended to increase when AMS was introduced. However, the differences were not significant. This phenomenon may partly be caused by shorter intervals in milking, which was also seen in the traditional milking system with increased milking frequency. Bruckmaier et al. (2001) found that the fat content increases when the milking interval is shorter. However, our results are in disagreement with the studies of Klun- gel et al. (2000) and Everitt et al. (2002). Klungel et al. (2000) found that fat and protein content was significantly decreased after the introduction of AMS (from 4.41 and 3.49 to 4.37 and 3.42, respectively). In a Swedish study carried out by Everitt et al. (2002) the fat (from 4.18 to $4.09 \%$ ) and protein (from 3.31 to $3.26 \%$ ) contents dropped after installation of AMS.

Elevated FFA levels indicate increased lipolysis of milk. Escobar and Bradley (1990) suggest that lipolysis is mainly caused by milk pipelines, but it can also be caused by bacteria, such as psychrotrophic bacteria (Shah 1994). The effect of mechanical treatment on milk causing lipolysis continues during storage (Needs et al. 1986). However, rapid cooling of milk has been reported to delay the lipolysis (Escobar and Bradley 1990). A recent report from Klungel et al. (2000) supports our findings. They also found a significant increase in FFA after introduction of AMS.

The FP of milk is measured to find out possible water addition in milk. In Finnish dairies the limit for rejection is adjusted to $-0.512^{\circ} \mathrm{C}$. A similar elevation of FP observed in our study, has also been observed by others (Klungel et al. 2000, Rasmussen et al. 2002). In our study the FP decreased after the introduction period. This phenomenon has also been reported by Everitt et al. (2002). Cleaning procedures can leave residues of water in pipe lines and thus changes in the FP can be a mark of water in the pipelines. Further, air intake and more frequent milking with the AMS can cause changes in the FP of milk (Klungel et al. 2000).

\section{Conclusion}

The present work was conducted on the first Finnish farms equipped with an AMS. The study showed that the bulk milk was not seriously altered by the implementation of AMS. The introduction of AMS tended to increase SCC, TBC, psychrotrophic and coliformic counts and the level of FFA and fat content of milk in Finland. However, the changes were not statistically significant. 


\section{Salovuo, H. et al. Introduction of automatic milking}

There were no major differences in counts of Clostridium spores and Bacillus cereus between the conventional system and AMS. The freezing point of milk was significantly increased after the installation of AMS and returned to the original level after an introduction period. Though the overall quality of milk tended to be impaired after the introduction of AMS, the quality of milk remained at premium class.

Acknowledgements. The authors gratefully thank the farmers and technical staff on the research farm for participating in this study. We also thank Valio Ltd for analysing samples, and the Finnish Ministry of Agriculture and Forestry and Valio Ltd for funding this research.

\section{References}

Akam, D.N., Dodd, F.H. \& Quick, A.J. 1989. Milking, milk production hygiene and udder health. FAO Animal Production and Health Paper 78. 119 p.

Aureli, P. \& Franciosa, G. 2002. Clostridium spp. In: Roginski, H. et al. (eds.). Encyclopedia of Dairy Sciences. London, UK: Academic Press. p. 456-463.

Bergere, J.L. \& Sivelä, S. 1990. Detection and enumeration of clostridial spores related to cheese quality - classical and new methods. IDF Bulletin 251: 18-23.

Berglund, I., Petterson, K. \& Svannersten-Sjaunja, K. 2002. Automatic milking: effects on somatic cell count and teat end-quality. Livestock Production Science 78: 115-124.

Bruckmaier, R.M., Macuhova, J. \& Meyer, H.H.D. 2001. Specific aspects of milk ejection in robotic milking: a review. Livestock Production Science 72: 169-176.

Christiansson, A., Bertilsson, J. \& Svensson, B. 1999. Bacillus cereus spores in raw milk: factors affecting the contamination of milk during the grazing period. Journal of Dairy Science 82: 305-314.

Cromie, S. 1992. Psychrotrophs and their enzyme residues in cheese milk. Australian Journal of Dairy Technology 47: 96-100.

Escobar, G.J. \& Bradley, R.L., Jr. 1990. Effect of mechanical treatment on the free fatty acid content of raw milk. Journal of Dairy Science 73: 2054-2060.

Everitt, B., Ekman, T. \& Gyllenswärd, M. 2002. Monitoring milk quality and udder health in Swedish AMS herds. In: The First North American Conference on Robotic Milking, Toronto, Canada. V-72-V-75.

FIL-IDF 1985. Milk and milk products. Enumeration of coliforms - Colony count technique and most probable number technique at $30^{\circ} \mathrm{C}$. FIL-IDF Standard 73A:1985. $8 \mathrm{p}$.

FIL-IDF 1989. Milkfat products and butter. Determination of fat acidity. FIL-IDF Standard 6B: 1989 (Provisional). 3 p.
FIL-IDF 1991. Milk. Enumeration of psychrotrophic microorganisms. Colony count technique at $6.5^{\circ} \mathrm{C}$. FIL-IDF Standard 101A:1991. 3 p.

Finnish Association for Milk Hygiene 2004. E-luokan osuus maidosta 1998-2004. http://www.maitohygienialiitto.fi/ laatu_E-luokan_os_03.html. Cited 14 September 2004.

Hamann, J. \& Gyodi, P. 2000. Somatic cell counts and electrical conductivity in relation to milking frequency. Milchwissenschaft 55: 303-307.

Hayes, M.C., Ralyea, R.D., Murphy, S.C., Carey, N.R., Scarlett, J.M. \& Boor, K.J. 2000. Identification and characterization of elevated microbial counts in bulk tank raw milk. Journal of Dairy Science 84: 292-298.

Hogeveen, H., Ouweltjes, W., de Koning, C.J.A.M. \& Stelwagen, K. 2001. Milking interval, milk production and flow-rate in an automatic milking system. Livestock Production Science 72: 157-167.

ISO 7932. Microbiology - General guidance for the enumeration of Bacillus cereus - Colony count technique at $30^{\circ} \mathrm{C}$. 2nd edition. International Organization of Standardization, Geneva, Switzerland. 1993.

Klijn, N., Nieuwnhof, F.F.J., Hoolwerf, J.D., van der Waals, C.B. \& Weerkamp, A.H. 1995. Identification of Clostridium tyrobutyricum as the causative agent of late blowing in cheese by species-specific PCR amplification. Applied and Environmental Microbiology 61: 29192924.

Klungel, G.H., Slaghuis, B.A. \& Hogeveen, H. 2000. The effect of the introduction of automatic milking systems on milk quality. Journal of Dairy Science 83: 19982003.

Needs, E.C., Anderson, M. \& Morant, S.V. 1986. Interaction of factors which influence the extent of lipolysis during milking and storage of raw milk. Journal of Dairy Research 53: 203-210.

Rasmussen, M.D., Bolm, J.Y., Nielsen, L.A.H. \& Justesen, P. 2001. Udder health of cows milked automatically. Livestock Production Science 72: 147-156.

Rasmussen, M.D., Bjerring, M., Justesen, P. \& Jepsen, L. 2002. Milk quality on Danish farms with automatic milking systems. Journal of Dairy Science 85: 28692878.

Schuling, H.J., Verstappen-Boerekamp, J.A.M., Knappstein, K. \& Benfalk, C. 2001. Optimal cleaning of equipment for automatic milking. Deliverable D16. Available on the Internet: http://www.automaticmilking.nl. Cited 18 March 2003.

Shah, N.P. 1994. Psychrotrophs in milk: a review. Milchwissenschaft 49: 432-437.

Slaghuis, B., te Giffel, M.C., Beumer, R.R. \& Andre, G. 1997. Effect of pasturing on the incidence of Bacillus cereus spores in raw milk. International Dairy Journal 7: 201-205.

Stadhouders, J. \& Jørgensen, K. 1990. Prevention of the contamination of raw milk by a hygienic milk production. IDF Bulletin 251: 32-36.

Suokannas, A., Salovuo, H., Ronkainen, P., Heino, A., Hovinen, M., Kasanen, I., Raussi, S., Kaihilahti, J., Aisla, A.-M., Saastamoinen, S., Alasuutari, S. \& Manninen, E. 2004. Maidon laatu, eläinten utareterveys, käyttäytyminen ja hyvinvointi automaattilypsyssä. Abstract: Effects 
Vol. 14 (2005): 346-353.

of automatic milking on the milk quality, udder health, behaviour and welfare of cows. Maa- ja elintarviketalous $62.97 \mathrm{p}$.

te Giffel, M.C., Beumer, R.R., Slaghuis, B.A. \& Rombouts, F.M. 1995. Occurrence and characterization of (psychrotrophic) Bacillus cereus on farms in the Nether- lands. Netherlands Milk and Dairy Journal 49: 125138.

Van der Vorst, Y. \& Hogeveen, H. 2000. Automatic milking system in the Netherlands. In: Robotic milking proceedings of the international symposium. Lelystad, Netherlands. p. 73-82.

\title{
SELOSTUS
}

\author{
Automaattisen lypsylaitteiston käyttöönoton vaikutus maidon laatuun \\ Heidi Salovuo, Pilvi Ronkainen, Antti Heino, Antti Suokannas ja Eeva-Liisa Ryhänen \\ Helsingin yliopisto ja MTT (Maa- ja elintarviketalouden tutkimuskeskus)
}

Lypsy ja siihen liittyvät työt muuttuvat tilalla, kun automaattinen lypsyjärjestelmä otetaan käyttöön. Tämän tutkimuksen tarkoituksena oli tutkia automaattisen lypsyjärjestelmän käyttöönoton vaikutusta maidon koostumukseen ja laatuun Suomessa. Tutkimus toteutettiin kolmella tilalla, jotka olivat ensimmäisiä automaattilypsytiloja Suomessa. Maidon kemiallinen koostumus, somaattiset solut, kokonaisbakteerit, jäätymispiste, vapaat rasvahapot, Bacillus cereus, klostridi-itiöt, psykrotrofit bakteerit, ja koliformiset bakteerit määritettiin. Automaattilypsyn käyttöönoton jälkeen somaattisten solujen, kokonaisbakteerien, psykrotrofisten ja koliformisten bakteerien määrät olivat korkeampia kuin perinteisesti lypsettäessä, mutta erot eivät olleet tilastollisesti merkitseviä. Klostridi-itiöiden määrä oli samalla tasolla automaattilypsymaidossa ja perinteisesti lypsetyssä maidossa. Bacillus cereuksen määrä oli hyvin alhainen molemmilla lypsytavoilla. Maidon rasvapitoisuus ja vapaiden rasvahappojen määrä kohosivat automaattisen lypsyn käyttöönoton jälkeen. Jäätymispiste kohosi ensimmäisten kolmen kuukauden kuluessa laitteiston käyttöönotosta. Vaikka maidon laatu heikkeni, se oli edelleen Eluokan maitoa. 